\title{
Stimuli towards well-being in an environment with Complementary and Integrative Practices (CIPs)
}

\author{
Estímulos ao bem-estar na ambiência de Práticas \\ Integrativas e Complementares (PIC)
}

\section{Mariana Silva Villela \\ Vera Helena Moro Bins Ely}

\begin{abstract}
his article presents a proposal to categorise stimuli that influence

well-being in therapeutic environments following Complementary and Integrative Practices (CIPs). With the broader aim of understanding which environmental stimuli influence the well-

being of CIP therapeutic environment users, this qualitative research adopted a multimethod approach: bibliographic and documentary research; walkthrough analysis; exploratory visits; environment observations; and finally, interviews. After cross-referencing a literature review and an environmental assessment of three case studies during 2017, a categorisation was drawn up, and it suggests that the stimuli which most influence well-being in CIP environments are: Artistic, Auditory, Biological, Luminous and Hygrothermal Comfort, Energetic, Spatial, Natural, Olfactory, Social and Socio-Spatial stimuli. Included in a broader debate on creating environments favourable to users' health, and in line with an increasing demand of CIPs in Brazil, this categorisation aims at contributing to the knowledge of CIP environmentspecific necessities and improving the quality from the early stage of project idealisation.

Keywords: Healthcare Architecture; Therapeutic Environment; Environment and Public Health; Complementary and Integrative Practices.

\section{Resumo}

Este artigo apresenta uma proposta de categorização dos estímulos influenciadores do bem-estar em ambientes terapêuticos de Práticas Integrativas e Complementares (PIC). Com o objetivo geral de conhecer os estímulos ambientais que influenciam o bem-estar de usuários de ambientes terapêuticos de PIC, a pesquisa qualitativa utilizou uma abordagem multimétodos: pesquisa bibliográfica e documental; análises walkthrough; visitas exploratórias; observações de ambientes; e, entrevistas. A partir do cruzamento de uma revisão de literatura e de uma avaliação ambiental

${ }^{1}$ Mariana Silva Villela ${ }^{1}$ Universidade Federal de Santa Catarina

Florianópolis - SC - Brasil

${ }^{2}$ Vera Helena Moro Bins Ely ${ }^{2}$ Universidade Federal de Santa

Catarina

Florianópolis - SC - Brasil

Recebido em 28/03/19 Aceito em 02/08/19

realizada em três estudos de caso, no ano de 2017, foi elaborada a categorização que sugere que os estímulos influenciadores do bem-estar em ambientes de PIC sejam: Artísticos; Auditivos; Biológicos; de Conforto Lumínico e Higrotérmico; Energéticos; Espaciais; Naturais; Olfativos; Sociais; e, Socioespaciais. Inserida em uma discussão mais ampla sobre a criação de ambientes favoráveis à saúde, e em consonância com uma crescente demanda pelas PIC no cenário nacional, a categorização visa contribuir ao conhecimento das necessidades ambientais específicas de PIC e ao incremento de sua qualidade, desde a etapa de idealização dos projetos.

Palavras-chave: Arquitetura de Instituições de Saúde; Ambientes Terapêuticos; Ambiente e Saúde Pública; Práticas Integrativas e Complementares.
\end{abstract}

VILLELA, M. S.; BINS ELY, V. H. M. Stimuli towards well-being in an environment with Complementary and Integrative 441 Practices (CIPs). Ambiente Construído, Porto Alegre, v. 20, n. 2, p. 441-456, abr./jun. 2020.

ISSN 1678-8621 Associação Nacional de Tecnologia do Ambiente Construído. 


\section{Introduction}

The therapeutic potential of environments has been explored within the realm of Architecture as a supporting strategy for promoting health and well-being (DO REGO, 2012; IYENDO; UWAJEH; IKENNA, 2016; PIZZOLATO, 2014; SHRAIKY, 2011; STERNBERG, 2009). After the World Health Organization (WHO) defined health beyond the realm of the individual, factors such as social interaction and environment are also considered as contributors to life quality and well-being, amplifying the understanding that health is more than just the absence of disease (WORLD..., 2014). Under this premise, learning which environmental stimuli influence the well-being of people becomes a challenge and a decisive factor in the quality of architectural design.

Regarding the architecture of health institutions - especially therapeutic environments - there has been consistent scientific knowledge underpinning projects of this nature over the last decades. Such project research and guidelines inform health-oriented settings in most Western countries whose architecture prioritises functional, technological and sanitary aspects (DO REGO, 2012; TOLEDO, 2006; CAVALCANTI, 2011; HEATHCOTE, 2015). However, very little attention has been given to environments of medical and therapeutic modes outside the Western medical tradition.

Formerly known as Alternative Medicine, more recently this approach has been called Traditional and Complementary Medicine (T\&CM) by the WHO (WORLD..., 2013) — such practices originate from native cultural beliefs and experiences and/or stem from national traditions and their main health systems. Complementary and Integrative Practices (CIPs), also known as Complementary and Integrative Medicine, refer to therapeutic practices of diverse complexity and draw from systems and therapeutic resources that derive from T\&CM and therefore encompass knowledge and techniques geared to the promotion of health (TESSER, 2009). CIPs may be applied as an isolated practice (e.g. Acupuncture, Meditation, Shiatsu, etc.) or may constitute a structured medical system (i.e. Ayurvedic, Homeopathic, Anthroposophic and Chinese medicinal modalities).

Since the early $21^{\text {st }}$ Century, the WHO encourages the establishment of local health policies that include such medical modalities (WORLD..., 2002; 2013). The increasing demand for CIPs is a worldwide phenomenon, and it can partially be explained due to the WHO's support to include them in public health policies and also the spontaneous people demand, for a number of reasons (low cost, less aggressive and more natural treatments, effectiveness of symptom relief, i.a.) (WORLD..., 2002, 2013; TESSER, 2010). Therefore, since the beginning of the 1970s, the encounter between T\&CM medical systems and medical systems practiced in Western countries, other medical specialties such as Naturology (SABBAG et al., 2013) and Integrative Medicine began to emerge (FRENKEL; COHEN, 2014; HORRIGAN et al., 2012; HU et al., 2015; MAIZES; RAKEL; NIEMIEC; 2009; OTANI; BARROS, 2011).

In Latin America, Brazil and Cuba include CIPs in their public health systems (GUIDO et al., 2015). In Brazil, after the launch of National Policies for Complementary and Integrative Practices (PNPIC) in 2006 (BRASIL, 2008), CIPs were integrated into the National Public Health System (SUS) - which currently offers 29 modes (VALADARES, 2018) in 9,350 health facilities in 3,173 cities (BRASIL, 2019). In addition, at the national level, CIPs are also available in private hospitals, clinics, medical offices and spas.

Despite the Ministry of Health having published a booklet with guidelines for the environment of SUS public health facilities (BRASIL, 2010), from the architectural point of view, the document does not distinguish CIP settings from regular health environments. Thus, for the conception of health institutions, architects must draw on guidelines brought forth by scientific research focusing on Western medicine or on specific health setting legislation and documents that refer to projects with similar kinds of environments.

Considering the shortage of studies on specific CIP settings and the consistent and increasing demand for such spaces, this research study is not only justified but also necessary since its main objective was to learn what environmental stimuli influence the well-being of CIP users. As a byproduct of the original research (VILLELA, 2017), this article focuses on already identified stimuli.

\section{The interfaces of human and environment interaction}

Human-environment interaction has been more intensively researched since the last quarter of the $20^{\text {th }}$ Century in different realms of knowledge and from a variety of perspectives: Architecture, Ergonomics, Neuroscience, Environmental Psychology, Public Health, i.a. Such studies fostered transdisciplinary debates that resulted in 
formulating theories and identifying relations between environmental elements and their psychological, physical, physiological and behavioural effects.

The establishment of favourable health environments as strategies to promote well-being has been in discussion since the promulgation of the Ottawa Charter for Health Promotion of 1986 (BRASIL, 2002). In architecture for therapeutic settings, most studies arise from ample discussions on the humanisation of health institutions, which began in the 1970s at the international level, and as of the 1990s, in Brazil. The result was a search for requalifying such environments by means of human-environmental strategies focusing on the recovery and well-being of its users (CAVALCANTI, 2011).

Investigating cognitive aspects and their relation to perceptions and behaviours was widely explored by Environmental Psychology researchers. Studies indicate that behaviour is affected by the individual's perception of his/her surrounding environment (GIFFORD; STEG; RESER, 2011; GIBSON, 1986; LOMBARDO, 1987). Furthermore, Stress Recovery Theory by Roger Ulrich, and Attention Recovery Theory by Rachel Kaplan and Stephen Kaplan, led to developing a concept for restorative environments whose elements or features favour the restoration of attention and recovery of psychophysiological stress (GRESSLER; GÜNTER, 2013; HARTIG, 2011; JOYE; VAN DEN BERG, 2012).

With the advance of neuroscience and psychoneuroimmunology, the interactions between behavior and the nervous, endocrine and immune systems were investigated (STERNBERG, 2009; FARLING, 2015). Such research highlights the negative influence of factors, such as environmental stress on an individual's immune system (e.g. anxiety caused by spatial disorientation in confusing environments) and also how positive experiences and emotions may lead to positive responses of the immune system in stressful conditions (e.g. the presence of vegetation or views of nature in environments) (GRESSLER; GÜNTER, 2013; JOYE; VAN DEN BERG, 2012).

As more research has been conducted, the idealisation of therapeutic environments has been scientifically supported in the formulation of guidelines and design recommendations oriented to the welfare of users, well consolidated by The Center for Health Design (CHD) in the United States, with the Evidence-based Design (EBD) method. EBD is a method that searches for scientific evidence for a given health setting, and its contribution to formulating guidelines for health setting design is, in fact, remarkable (FARLING, 2015). For example, for longer inpatient treatments, Ulrich identified the main components for environment-related stress and devised the Supportive Design Theory which provided guidance for projects and hospital environmental design that would lead to the decrease of users' stress and anxiety (ULRICH, 1991).

\section{The phenomenon of Ambience and environmental stimuli}

From the perspective of Architecture, the phenomenon of environmental design became the conceptual starting point for this research. Based on the theoretical scope of Phenomenology, Malard pointed out that among the phenomena that occur in a process of inhabitancy (how people experience a building), the Ambience combines the sum of qualities of the internal spaces, where the human senses are stimulated (MALARD, 2006). For the Ambience, three other inhabitancy phenomena converge: Territoriality, Privacy and Identity, which are also related to more abstract dimensions, such as interior and exterior, visibility and appropriation. Territoriality encompasses aspects such as security, physical barriers, demarcation of spaces, hierarchy of spaces, etc. Privacy encompasses aspects such as controlling access to places and people, visual and/or acoustic barriers, intimacy, etc. Identity encompasses individual or group expression, customisation, personality of places, etc.

As all of the inhabitancy phenomena converge to Ambience, the environment may provoke behavioural aspects directly related to architectural features and elements. From a physical or physiological dimension, human senses may be stimulated by aspects such as acoustic, ergonomic, luminous and thermal comfort, i.a. From a psychological dimension, human senses may be stimulated by scents, colours, sounds, textures, etc.

Among the many benefits resulting from environmental stimuli that promote wellness, are behavioural, physical, physiological and psychological effects such as: enhancement of the circadian cycles and of certain sensations and/or behaviours; improvement of psychological conditions (stress, anxiety and insecurity) and perception of pain levels; preventing contamination, fatigue, accidents and medical errors; stabilisation of respiratory rhythm, heartbeat and blood pressure, i.a. The stimuli will be presented, in detail, in Section Results and synthesis. 


\section{Methodology}

The methodology was planned to fulfil the main objective of this research: Finding out which-environmental stimuli influence user well-being in therapeutic settings that follow CIPs - users being those who give or receive treatment. This study followed the Cycle of Qualitative Research, comprising three phases: Exploratory phase, Fieldwork, and Analysis and Treatment of Material (MINAYO, 1994).

In the Exploratory phase, the scope of the study was defined, its theoretical and methodological development was carried out, and the research procedures were outlined, including bibliographical, documentary research techniques and the narrowing down of the subject.

Case studies were selected according to whether the public and private institutions, which provide health care or teaching facilities, offered different CIP therapies and whether they offered environments that qualified for the activities sought in this study. Thus, three places were chosen: Projeto Amanhecer/NUAM at the Professor Polydoro Ernani de São Thiago University Hospital at the Federal University of Santa Catarina (UFSC) in Florianópolis, SC; Centro de Práticas Naturais (Center for Natural Practices), which is the School-Clinic of the Naturology Course from UNISUL in Palhoça, SC; and the Spa \& Wellness Center - a School-Spa from University Anhembi Morumbi, in São Paulo, SP. These health settings are all linked to universities and offer therapeutic health and wellness services to the broader community.

During the Fieldwork, the theoretical and methodological constructs of the experiment were applied in two stages. In the first one, exploratory visits to the institutions were made to familiarise ourselves with the facilities and learn about their operational structure, observing and documenting (walkthrough procedure) each environment when not in use; in the second stage, visits were made to observe and document the environments while in use, gathering opinions, information and interviewing users. The health environments chosen for the study were selected with the institutions' supervisors; the same occurred when selecting the therapists and persons in treatment for interviews and systematic observation. The selection criteria for interviewees included: stable physical and emotional conditions to communicate with the researcher; type of pathology or therapy; and age bracket, minors were excluded. Any sort of embarrassment towards interviewees was avoided.

The observation was carried out systematically, with a specific observation chart, in all therapeutic environments (when not in use), and twelve environments in use, totalling 24 hours of observation. Forty interviews were conducted in loco, with thirty-eight users (among therapists and persons in treatment, as well as supervisors in charge) and with two experts in the field, totalling 25 hours of interviews.

During the Analysis and Treatment of Material stage, data obtained from the Fieldwork was dealt with using the Content Analysis technique (BARDIN, 1977), so as to decode the collected messages and categorise the content according to its relevance for the study. Formal authorisations were obtained from the institutions participating in the research, and the research project was submitted to the Ethics Committee for Research with Human Beings (CEPSH), having been entirely approved.

\section{Results and synthesis}

In this section, the identification of environmental stimuli influencing well-being is presented, categorised into two stages: First, as they appear in the scientific literature in the Western medical context; and then, as they appear in the specific CIP contexts, a cross-referencing between bibliographical review and fieldwork.

\section{First categorisation of stimuli: the contribution of scientific literature}

The identification of stimuli favourable to wellness in therapeutic environments - elements and features - was conceived according to the nature of each stimulus. Such grouping provided a first categorisation in an effort to synthesise the research references (some results were incongruous due to varying research focuses), eliminate redundancies and objectify the identification of stimuli.

Stimuli identified in this stage were: Artistic, Auditory, Biological, Luminous and Hygrothermal Comfort, Spatial, Natural, Olfactory, and Psychological, as demonstrated in Table 1.

This initial categorisation favoured the choice of instruments for data collection and was used as the basis to understand how the stimuli are applied within the context of therapeutic settings. 


\section{Second categorisation of stimuli: the contribution of data collection to case studies}

The quantitative analysis of the data obtained from the Fieldwork, with all the methods, led to revising and reformulating the stimuli from the first categorisation.

\section{Table 1 - First stimuli categorisation (Continues...)}

\begin{tabular}{|c|c|c|}
\hline Stimuli & Examples & Influence on well-being \\
\hline \multirow{2}{*}{$\begin{array}{l}\text { ARTISTIC: } \\
\text { Significant elements in } \\
\text { volume, texture and } \\
\text { colour, such as ornaments, } \\
\text { installation and artistically } \\
\text { represented natural } \\
\text { elements. }\end{array}$} & $\begin{array}{l}\text { Natural elements in various } \\
\text { media (paintings, TV, } \\
\text { photographs, projections, } \\
\text { etc.) }\end{array}$ & $\begin{array}{l}\text { Micro-restorative properties of attention and stress } \\
\text { reduction; relaxation; positive emotions (IYENDO; } \\
\text { UWAJEH; IKENNA, 2016; JOYE; VAN DEN BERG, } \\
\text { 2012; LANKSTON et al., 2010). }\end{array}$ \\
\hline & $\begin{array}{l}\text { Art (artistic ornaments such } \\
\text { as paintings, photographs, } \\
\text { sculptures, etc.) }\end{array}$ & $\begin{array}{l}\text { Attention restoration and stress reduction, promotion of } \\
\text { relaxation, positive emotions (GRESSLER; GUNTER, } \\
\text { 2013; IYENDO; UWAJEH; IKENNA, 2016; LANKSTON } \\
\text { et al., 2010; SHEPLEY; PASHA, 2013; ULRICH, 1991). }\end{array}$ \\
\hline
\end{tabular}

\section{AUDITORY:}

Presence of sound and/or silence in environments.

\section{BIOLOGICAL:}

Factors or elements that aim to guarantee the user's safety eliminating any toxicological or contaminating factor.

\section{LUMINOUS AND HYGROTHERMAL COMFORT:}

Natural resources and artificial ventilation and lighting, temperature control and environmental humidity.
Sounds (soft music, natural sounds)

Silence (noise reduction)

Elimination of environmentally toxic or contaminating factors

Hygiene and maintenance practicality

Equipment (control of biological indexes, etc.)

Natural lighting

(controllable with blinds, curtains and brise-soleil)

Artificial lighting (automatically controlled, dimmer and direction control)

\section{Natural ventilation (controllable with screens and fenestration)}

Mechanical ventilation (automatically controlled)
Distraction, relaxation, reduction of psychological and physiological stress (IYENDO; UWAJEH; IKENNA, 2016; SCHWEITZER; GILPIN; FRAMPTON, 2004;

THOMSON; PETTICREW, 2005; ULRICH et al., 2004; VAN DEN BERG, 2005).

Improvement of inpatient sleep quality; emotional stress reduction; reduction of pain medication (IYENDO; UWAJEH; IKENNA, 2016; SCHWEITZER; GILPIN; FRAMPTON, 2004; SHEPLEY; PASHA, 2013; ULRICH, 2000; 2004).

Safety, intoxication and/or contamination prevention (SCHWEITZER; GILPIN; FRAMPTON, 2004; SHRAIKY, 2011; THOMSON; PETTICREW, 2005; ULRICH et al., 2004).

Safety, sanitation (IYENDO; UWAJEH; IKENNA, 2016; SCHWEITZER; GILPIN; FRAMPTON, 2004; SHEPLEY; PASHA, 2013; THOMSON; PETTICREW, 2005).

Safety (SHEPLEY; PASHA, 2013).

Visual and psychological comfort; safety in clinical procedures (IYENDO; UWAJEH; IKENNA, 2016; SHEPLEY; PASHA, 2013; ULRICH et al., 2004; VAN DEN BERG, 2005).

Visual comfort; safety in clinical procedures (SHEPLEY; PASHA, 2013; SHRAIKY, 2011; ULRICH et al., 2004).

Thermal and psychological comfort, air quality (IYENDO; UWAJEH; IKENNA, 2016; THOMSON; PETTICREW, 2005; ULRICH et al., 2004; VAN DEN BERG, 2005).

Thermal comfort, air quality (THOMSON; PETTICREW, 2005; ULRICH et al., 2004).

Source: adapted from Villela (2017). 
Table 1 - First stimuli categorisation (continued)

\section{SPATIAL:}

Elements and attributes planned from the beginning of construction regarding architectural, constructive and functional aspects, as well as indoor layouts.

\section{NATURAL:}

Presence of natural elements such as vegetation, water, animals, natural sounds, among others, in natural landscapes.

Gardens

Natural elements inserted in artifacts (fountains, vegetation in fire in fireplace, fish in aquariums, etc.)

Layout

Furniture

Equipment (to help move around, etc.)

Adaptability and flexibility (spatial configuration liable to change)

Presence of signs (wayfinding)

Environment hierarchy (wayfinding)
External views, natural lighting (SHEPLEY; PASHA, 2013; SHRAIKY, 2011; ULRICH et al., 2004).

Sense of tranquility/quietness, comfort, cosiness (IYENDO; UWAJEH; IKENNA, 2016; SHEPLEY; PASHA, 2013; SHRAIKY, 2011).

Universal Design

Safety, decrease in risk of falling and accidents; design that helps to access, understand and use an environment (THOMSON, PETTICREW, 2005).

Sense of comfort, cosiness, hygiene, safety (risk of falling) (SHEPLEY; PASHA, 2013; THOMSON; PETTICREW, 2005; ULRICH et al., 2004).

Adequacy for specific activities (SHEPLEY; PASHA, 2013; SHRAIKY, 2011).

Adequacy for specific activities (SHEPLEY; PASHA, 2013; SHRAIKY, 2011).

Adequacy for specific activities, safety (SHEPLEY; PASHA, 2013).

Layout adequacy, furniture and other elements regarding activities, to increase privacy, and space appropriation, etc. (SHEPLEY; PASHA, 2013; SHRAIKY, 2011; TISSOT, 2016).

Spatial autonomy (SHRAIKY, 2011; STERNBERG, 2009; ULRICH et al., 2004).

Help in understanding space layout (SHRAIKY, 2011; STERNBERG, 2009; ULRICH et al., 2004).

Attention restoration and stress reduction, leisure, positive distractions (GRESSLER; GÜNTER, 2013; IYENDO; UWAJEH; IKENNA, 2016; JOYE; VAN DEN BERG, 2012; KAPLAN, 1995; SHEPLEY; PASHA, 2013; SHRAIKY, 2011; ULRICH, 1991).

Attention restoration and stress reduction (GRESSLER; GÜNTER, 2013; IYENDO; UWAJEH; IKENNA, 2016; SHEPLEY; PASHA, 2013; SHRAIKY, 2011; ULRICH, 1984, 1991; VAN DEN BERG, 2005).

Attention restoration and stress reduction, leisure (IYENDO et al., 2016; JOYE; VAN DEN BERG, 2012; SHRAIKY, 2011; ULRICH, 1991; VAN DEN BERG, 2005).

Attention micro-restorative properties and stress reduction (JOYE; VAN DEN BERG, 2012; VAN DEN BERG, 2005).

Source: adapted from Villela (2017). 
Table 1 - First stimuli categorisation (continued)

\begin{tabular}{|c|c|c|}
\hline \multirow{2}{*}{$\begin{array}{l}\text { PSYCHOLOGICAL: } \\
\text { Environment characteristics } \\
\text { that allow user to reduce } \\
\text { stress and anxiety level; } \\
\text { also, the possibility to } \\
\text { socialise with other } \\
\text { environment users. }\end{array}$} & $\begin{array}{l}\text { Preference/ personal } \\
\text { satisfaction }\end{array}$ & $\begin{array}{l}\text { Favourite environment, attachment to the place, } \\
\text { invoking positive memories (GRESSLER; GÜNTER, } \\
\text { 2013; THOMSON; PETTICREW, 2005). }\end{array}$ \\
\hline & $\begin{array}{l}\text { Sense of control and } \\
\text { privacy/territoriality }\end{array}$ & $\begin{array}{l}\text { Control over personal circumstances; sound and } \\
\text { television controls, etc. (IYENDO; UWAJEH; } \\
\text { IKENNA, 2016; SHEPLEY; PASHA, 2013; } \\
\text { ULRICH, 1991; ULRICH et al., 2004). }\end{array}$ \\
\hline
\end{tabular}

Source: adapted from Villela (2017).

The technique of categorising by theme, employed in Content Analysis (BARDIN, 1977) was followed using the codification of the collected material (raw data), grouping them according to the relevance of meaning for analytical objectives. During this stage, it was noticed that the classification in progress almost completely matched the categorisation established earlier, derived from the literature review. Thus, the classification process was inverted, and the initial categorisation of stimuli was adopted, revised and complemented.

The research proposed two themes: "Significance of well-being as perceived by users", to identify a concept for wellness according to therapeutic environment users, and "Environmental stimuli influencing wellness", to identify and assess the influence each stimulus causes (positive or negative).

From the eight initial categories, recasting led to the codification of three more categories. For the theme "Significance of well-being as perceived by users", one single category was codified, and called "Psychological”, which defines psychological aspects according to the users' understanding of well-being. The aspects were identified partially by the researcher's observation and further informed by input from interviews. The theme "Environmental stimuli influencing wellness" codified ten categories. The stimuli corresponding to the category of observable physical aspects are: Artistic, Auditory, Biological, Luminous and Hygrothermal Comfort, Spatial, Natural, and Olfactory. Within the category of observable behavioural aspects are the Social and Socio-spatial stimuli (these unfolded from the earlier category Psychological aspects, from the initial categorisation). Finally, the Energetic stimuli are included in the category of subtle non-observable aspects. Figure 1 presents a synthesis of the resulting categorisation.

The category called Psychological, which resulted from the second categorisation, is restricted to aspects which the users see as significant in terms of well-being. The identified subcategories are as follows: Welcomeness - Perception of feeling welcome and at ease in a given environment; Motivation Willingness on the part of the user to engage in the therapeutic activities; Beauty - Perception of environmental aesthetics; Concentration - Perception of the user's degree of attention during therapeutic activities; Trust - Sensation of being in a safe environment, free of the phobias to engage in a treatment; Relaxation - User's restfulness to engage in the treatment, a sensation that resulted from the environmental or therapeutic stimuli; and Simplicity — Perception of environmental aesthetics without excess.

\section{Environmental stimuli influencing user wellness in CIP settings}

Systematic observations and interviews were the methods which most helped to identify stimuli in the case studies. Due to the availability of offers from the institutions when the data was collected, most observations were made in CIPs given individually (mostly the user lying on a treatment table), in private settings (only one therapist and one person being treated) or collective (several individual treatments in one room). This method identified the functional, physical and behavioural aspects. Regarding the interviews, most participants stated they had perceived the influence of the environment in their well-being, concerning not only functional, physical and behavioural aspects but also psychological ones. These ten categories are presented next. 
Figure 1 - Categorisation of thematic analysis

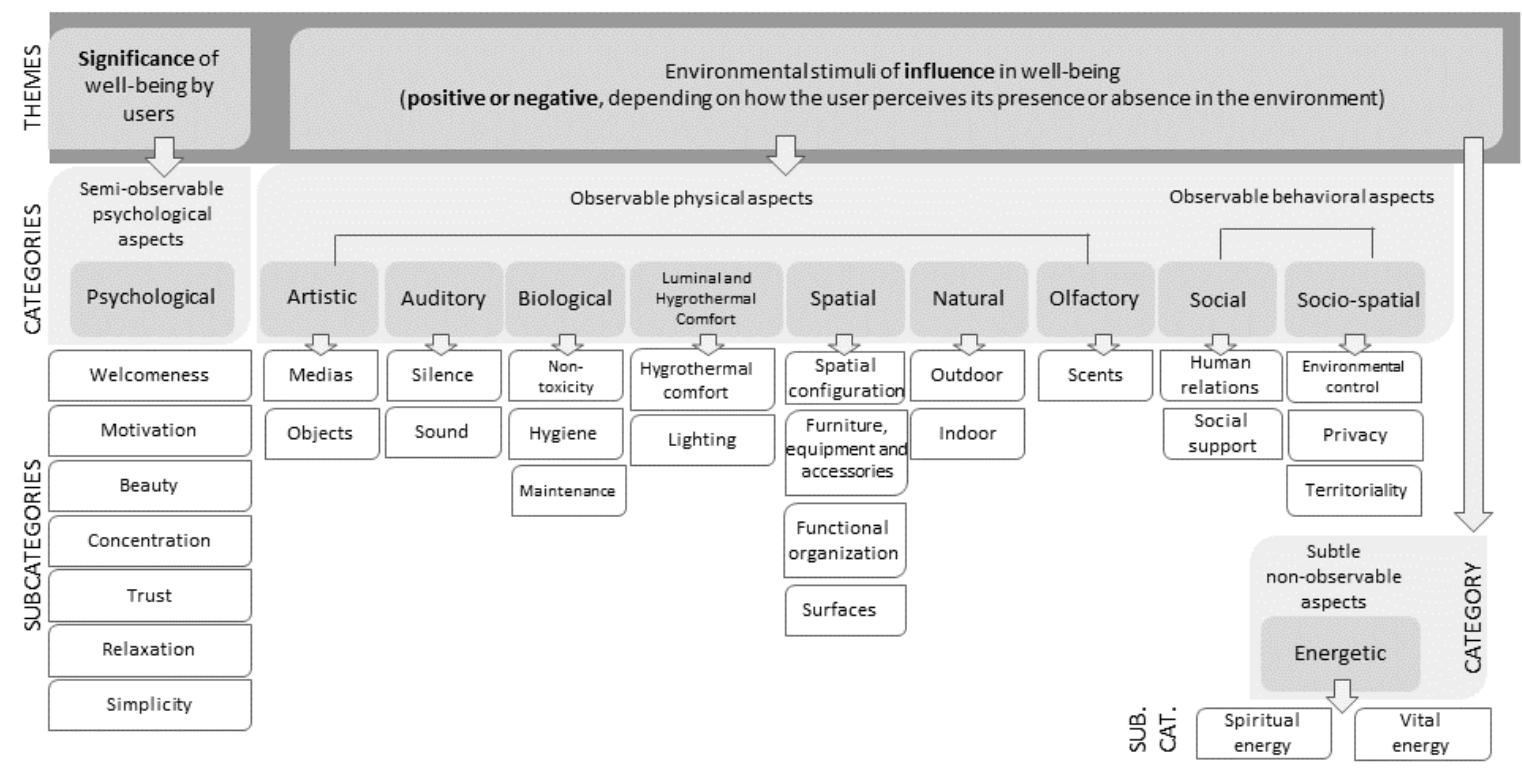

Source: Villela (2017)

\section{Artistic}

The Artistic category encompasses media elements (electronic media broadcasting artistic information) and objects (photograph panels, ornaments, etc.), present in all study cases. According to the literature, the presence of such elements may lead to micro-restoration of attention and stress reduction (see Figure 1).

The artistic elements were hardly mentioned spontaneously by users; however, they were positively associated with the possibility of leading users to a contemplative state. The lack of more examples of this category in the institutions hindered the observations.

\section{Auditory}

The Auditory category includes the Silence (absence of sounds) and Sounds (music and noises) subcategories. According to the literature, the presence of sounds and noise may alter the physiological indexes such as heartbeat, breathing, blood pressure i.a. The negative effects of noise can be related to inadequate decibel levels, negative emotions and difficulty in focusing on attention. The positive effects of Auditory stimuli relate to the absence of noise and/or presence of soft music (see Figure 1).

In the case studies, the effects of sounds apply to the moments prior to and during the treatment. Silence in the setting was appreciated by $89.5 \%$ of the interviewees, since most CIPs actually require concentration and relaxation. Noises were observed in all case studies. The presence of soft music was valued as positive for approximately half of the interviewees. Nature sounds (e.g. birds singing) were also positively evaluated.

\section{Biological}

This category comprises the Non-toxicity (environments using non-toxic materials), Hygiene (cleanliness of environment and equipment) and Maintenance (easiness to keep the environment clean and integrity of tile lining) subcategories. The scientific literature indicates that Biological stimuli relate to safety issues, especially hygiene and elimination of toxic or contamination factors (see Figure 1).

The Hygiene subcategory was valued by most users and related to psychological aspects of safety and contamination, institutional trust, sense of relaxation and perception of comfort and beauty. During the practices involving application of oils, creams, mud, etc., the environments offered soap dispensers, towelhangers, etc., and lavatories. Even when the therapists did not touch the person, they would wash their hands before and after treatment.

The Maintenance and Non-toxicity subcategories were barely mentioned. Concerning the former, it was associated with easiness in the maintenance of the tile lining materials and furniture. The latter was associated 
with the possibility of users' allergic reactions when scented products (incenses, oils, etc.) were applied, and air saturation caused by strong odours of specific procedures, such as moxibustion or shirodhara.

\section{Luminous and Hygrothermal Comfort}

This category encompasses the Lighting Comfort (natural or artificial) and Hygrothermal Comfort (ventilation, temperature and humidity) subcategories. Regarding Lighting, the literature states that the influence on well-being refers to visual and psychological comfort and to the safety of clinical procedures. As for Hygrothermal Comfort, the literature associates quality of air, thermal and psychological comfort with natural ventilation and quality of air, thermal comfort with mechanical ventilation (see Figure 1). Most of the interviewees perceived the influence of this category on their well-being.

Regarding Lighting, the perception of Psychological Comfort varied among the users: dimmer lights were associated with relaxation and concentration and more light to beauty, comfort, cleanliness. It was observed that procedures requiring substance manipulation were conducted with the lights on (e.g. Acupuncture and Geotherapy); procedures with body manipulation were conducted with dimmed lights (e.g. Reflexology and Craniosacral Therapy); and procedures which rarely required touching were done in semi-darkness (e.g. Reiki). In addition to the existence of windows, devices such as coloured lights, dimmers, lighting fixtures and blinds also help to control luminosity, which can vary within one treatment session.

Regarding Hygrothermal Comfort, a negative influence was related to psychological discomfort when the environment was underventilated and/or without natural ventilation, and discomfort caused by cold or heat. Air-conditioning, windows, blankets, thermal blankets etc. were perceived as positive influences. No problems were observed concerning humidity.

\section{Spatial}

This category encompasses the elements related to space, with subcategories such as Spatial Arrangement of the environments (structuring elements of space, such as form, dimensions and fenestration), Furniture, Equipment and Accessories (elements that enable the activities in the environments), Functional Organisation (configuration of elements such as furniture and/or flexibles within the available space, by means of layout, universal design and wayfinding) and Surfaces (materials, colours, textures and surface finishing in the environment). In the literature, the spatial elements refer mainly to perception of welcomeness, functional organisation and adequacy for treatment purposes (see Figure 1).

Elements of the Spatial category were mentioned by $94.74 \%$ of the interviewees concerning perception of wellness and influence in the activities. In the Spatial Configuration subcategory, one of the items most mentioned was the perception of spaciousness: Confined environments and/or with restricted mobility, which do not allow the activities to be carried out satisfactorily, were seen negatively. In the Functional Organisation subcategory, layout was the item most mentioned as influencing well-being. Treatment tables lined up against the walls and little space between them was mentioned (in case of collective treatments) as negative.

Concerning the Furniture, Equipment and Accessories category, the treatment table was the item mentioned by the majority. For the therapists, the possibility of adjusting the height and being able to move around it was positively perceived. For the people in treatment, however, the treatment table should be comfortable and wide (for their safety when they needed to change positions). Other items, such as lavatories, hygienic accessories, pillows, cushions, tables and chairs were also perceived positively as they foster better results in the activities. Equipment and accessories are frequently provided by the therapists to enhance therapeutic environments, such as coloured lights, substances such as creams and oils, and various types of hygienic supports.

Finally, the Surfaces subcategory was frequently mentioned by the interviewees as an element for a welcoming, cosier environment (coatings and finishing touches in natural shades), relaxation (soothing colours) and neutrality (colours in light shades, such as white and grey). The sense of welcomeness was perceived as positive by interviewees in all samples. Relaxation was also perceived positively. Neutrality, however, was perceived negatively when associated with impersonality, and positively, when associated with simplicity and absence of distractors (enabling focus and concentration). Natural flooring and wall finishing stood out among therapists who work barefoot as they prefer a thermally comfortable floor, such as natural wooden floors. 


\section{Natural}

This category encompasses the Indoor (natural elements such as vases, water fountains, etc.) and Outdoor (landscapes viewed from the window, gardens, natural environments) subcategories. In the literature, stimuli from contact with nature or natural elements have properties that restore the attention span and decrease stress; these elements have a humanising factor because they represent positive distraction (see Figure 1).

The spontaneous mentioning of nature as an important component for the environment and well-being amounted to $78.95 \%$ of interviewees: This refers to the desire to be in contact with nature during their treatment, and the presence of natural elements in ideal treatment environments, as well as the positive perception of natural environments in the case studies. Some interviewees preferred to wait outside for their turn to be treated, in the garden (when there was one), instead of staying inside, in the waiting room, because it allows for contemplation and introspection. Natural elements were associated with the presence of beauty, relaxation, quietness and concentration; photographic and pictorial elements were also seen positively since they portray nature.

\section{Olfactory}

This category includes only one subcategory: Scents (present in the therapeutic setting).

Olfactory stimuli are not cited very often in the literature. When mentioned, it only indicates that pleasant scents in the environment promote relaxation, reduce stress and the perception of pain (SCHWEITZER et al., 2004), or it suggests that studies on scents involve many non-controllable variables, such as memories or individual cultural aspects (STERNBERG, 2009).

It was observed that Aromatherapy is used as a complementary technique in several CIP treatments, and is often cited by therapists as an inducer of relaxation. In addition, users in treatment sometimes associate pleasant scents with welcomeness.

\section{Social}

This category includes subcategories such as Human relations (personal interactions) and Social Support (possibility of interacting by means of spatial organisation). The subcategory Human Relations was included because, even when asked about the environment, many of the users' answers were about people. From a phenomenological perspective, such permeability between subject and object is understandable because it is the experiences and human relations that bring meaning to architecture, which is referred to as the phenomenon of ambience. Human relations are valued by people in treatment when they perceive the presence of lovingness, empathy and welcomeness. For the therapists, on the other hand, human relations are valued when a therapeutic bond is established. Systematic observation made it clear that gestures such as a hug, a smile, a warm welcome exchanged between people in treatment and therapists, were valued in all case studies.

In the literature, the Social Support subcategory is associated with lounge areas for socialisation and leisure (see Figure 1) as they induce stress reduction and mutual support. Very appreciated in hospital environments, especially for long inpatient treatments, this category was mentioned only by one interviewee. Both the people in treatment and the therapists, between sessions, realise that their well-being is related to states of relaxation, contemplation, meditation or the ability to maintain their concentration.

\section{Socio-spatial}

This category includes the Privacy, Ambience Control and Territoriality subcategories, all of which are behaviours that originate from the human-environment interaction. The literature considers these subcategories as humanising components in health institutions (see Figure 1).

Concerning Privacy, most interviewees mentioned the inadequacy of auditory privacy in environments with noise as it hinders concentration and relaxation. Visual privacy is perceived as positive in environments where individual treatments are conducted. In collective treatments, it was observed that visual privacy was taken care of with partitions or it was not important at all, since both the people in treatment and the therapists had their eyes closed for most of the treatment (e.g., collective Reiki sessions).

Regarding Environment Control, this is a less stressful factor in CIP environments than in hospitals as users stay in these settings for a short period of time. Users undergoing treatment do not have access to any sort of control, while the therapist controls the air-conditioning, lighting and sound (except in institutions where the sound system is central). In one of the settings, the control to access treatment rooms was granted to the 
therapists, while in most institutions, where the therapists were only interns, they did not have control over the access to rooms because their supervisors could come in and leave the rooms during the sessions.

Territoriality (demarcation of different spaces) appears in case studies as a possibility to arrange furniture according to treatment needs and to make rooms look more personal, using vases, candles, crystals, etc. In both cases, Territoriality is perceived positively by users.

\section{Energetic}

This category includes the Vital Energy (life sustaining energy) and Spiritual Energy (extra-physical human dimension) subcategories. The codification of Energetic stimuli was created exclusively as a result from the interviews (it appeared in all samples), because it was not brought forth by the scientific review. From the vitalist perspective, shared by various CIPs, nature, environment and living beings are permeated with vital energy ( $k i$, chi, prana, etc.) which sustains all forms of life. Some CIPs developed techniques for the manipulation of this energy (TESSER, 2009). In addition, because most people understand that health includes other dimensions beyond the psycho-physical one, many CIPs also take into account the spiritual dimension.

\section{Synthesis of possible influences of CIP environments on wellness}

In general terms, the perception of well-being stemming from environmental stimuli triggers more than one category or subcategory. Figure 2 synthesises the possible environmental influences on well-being of CIP users in this research study.

Figure 2 - Synthesis of possible influences on the well-being of CIP setting users (Continues...)

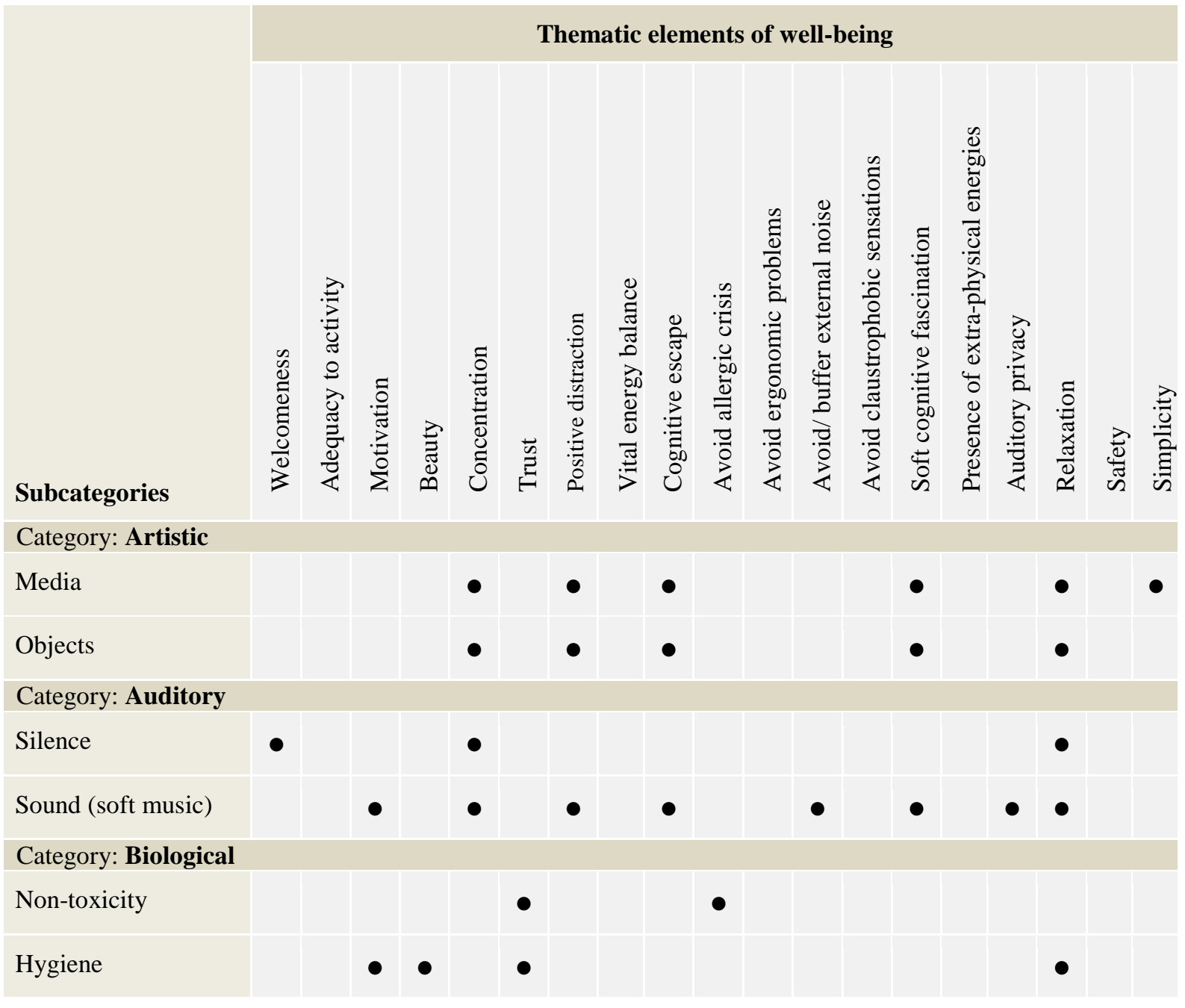

Source: adapted from Villela (2017). 
Figure 2 - Synthesis of possible influences on the well-being of CIP setting users (continued)

Maintenance

Category: Luminous and Hygrothermal Comfort

Hygrothermal

Comfort

Lighting

Category: Spatial

Spatial configuration

Furniture, equipment and accessories

Functional

Organisation

Surfaces

Category: Natural

Outdoor

Indoor

Category: Olfactory

Scents

Category: Social

Human Relations

Social Support

Category: Socio-spatial

Environment control

Privacy

Territoriality

Category: Energetic

Spiritual energy

Vital energy

Source: adapted from Villela (2017).

Since the focus of this research was on CIP studies conducted individually, it was observed that concentration and relaxation were the most valued factors contributing to the efficacy of the techniques. Benefits coming from environmental stimuli can also help those who are more sensitive towards environments or those who have more trouble relaxing. To address this problem, some stimuli may influence the user more before the treatment session (Artistic, Biological, Natural and Spatial) while other stimuli exert more influence during the session (Auditory, Olfactory, and Luminous and Hygrothermal Comfort). 
Sometimes the interviewees could not identify what exactly influenced their perception of well-being. Since the environment combines simultaneously captured sensorial stimuli, that can be explained as a perception of the atmosphere, or an essence of the space, endorsing the Ambience phenomenon. According to Pallasmaa (2015), this multisensorial capacity is associated to the right side of the brain, suggesting that we identify the whole prior to its parts and details.

\section{Conclusions}

The analysis of results called attention to the particularities of human-environment interactions in CIPs, which demand differentiated attention towards the idealisation of therapeutic settings compared to environments in health institutions from the Western medical tradition.

Besides the objectivity of the scientific evidence that environments do influence well-being, subjective aspects involved in the perception of users' well-being in CIP therapeutic environments also have to be taken into account. For example, people in treatment are often stimulated to reach what some therapists call the "internal environment": a mix of concentration, relaxation and receptive predisposition to treatment. An assertive architectural design can help in this case as the ambience phenomenon can provide relaxing stimuli for some people, especially those who are more environmentally sensitive.

Furthermore, from the architectural perspective, a design that acknowledges the needs of its potential users favours a more assertive execution of its construction, the activities to be carried out and encourages the possibilities of appropriation of space by its users.

When CIP environments are idealised, some stimuli are taken into account and defined before the actual construction; others are defined later on. Examples of aspects that can be defined during the design phase are folding screens and partitions, fenestration and tile finishing; layout and furniture may also be previously defined. These aspects are the main generators of Spatial stimuli, Luminous and Hygrothermal Comfort, as well as Biological and Socio-spatial stimuli. Examples of the latter, which do not depend on the construction project, are decorative elements, such as vases, planters with vegetation (Natural stimuli), paintings, panels, etc. (Artistic stimuli), and the presence of elements whose therapeutic aim is to provide relaxation/concentration through scents (Olfactory stimuli) and music (Auditory stimuli).

Because of their universal characteristic, some stimuli identified in individual treatments are applicable in other modes and CIP environments, such as group activities (Yoga, Tai-chi-chuan, etc.): scents, silence, and soothing sounds, for relaxation; art and nature contemplation for cognitive escape and positive distraction; design of a welcoming and relaxing atmosphere through spatial stimuli; natural lighting and ventilation, for the promotion of a positive psychological state (e.g., trust) and for the prevention of stressing or claustrophobic effects, i.a. This article aims to present the identified environmental stimuli that influence the well-being of CIP users, and, consequently, to contribute to the understanding of specific CIP environmental needs, an area which seems to lack in scientific research. In addition, due to the increasing and consistent presence of such environments in Brazil, especially in SUS, establishing architectural design guidelines for CIPs is extremely important.

\section{References}

BARDIN, L. Análise de Conteúdo. Lisboa: Edições 70, 1977.

BRASIL. Ministério da Saúde. Departamento de Atenção Básica. Portal da Saúde do SUS. PNPIC. Onde tem PICS? Available: http://dab.saude.gov.br/portaldab/ape_pic.php?conteudo=onde_tem_pics. Access: 14 nov. 2019.

BRASIL. Ministério da Saúde. Ministério da Saúde. Secretaria de Atenção à Saúde. Departamento de Atenção Básica. Política Nacional de Práticas Integrativas e Complementares no SUS. Brasília: Editora do Ministério da Saúde, 2008.

BRASIL. Ministério da Saúde. Secretaria de Atenção à Saúde. Núcleo Técnico da Política Nacional de Humanização. Ambiência. 2a ed. Brasília: Editora do Ministério da Saúde, 2010.

BRASIL. Ministério da Saúde. Secretaria de Políticas de Saúde. Projeto Promoção da Saúde. As cartas de promoção da saúde. Brasília: Editora do Ministério da Saúde, 2002.

CAVALCANTI, P. B. A humanização de unidades Clínicas de Hospital-Dia: vivência e apropriação pelos usuários. Rio de Janeiro: UFRJ, 2011. 
DO REGO, D. P. S. A arquitectura como instrumento medicinal: o papel terapêutico dos espaços da saúde na sua missão de curar e cuidar. Lisboa: Instituto Técnico de Lisboa, 2012.

FARLING, M. From intuition to immersion: architecture and neuroscience. In: ROBINSON, S.; PALLASMAA, J. [org.]. Mind in architecture: Neuroscience, Embodiment and the Future of Design. Cambridge: MIT Press, 2015.

FRENKEL, M.; COHEN, L. Effective communication about the use of complementary and integrative medicine in cancer care. The Journal of Alternative and Complementary Medicine, v. 20, n. 1, p. 12-18, 2014.

GIBSON, J. J. The ecological approach to visual perception. New Jersey: Lawrence Erlbaum Associates, 1986.

GIFFORD, R.; STEG, L.; RESER, J. P. Environmental Psychology. In: MARTIN, P. R. et al. (ed.) IAAP Handbook of Applied Psychology. Chichester: Wiley-Blackwell, 2011.

GRESSLER, S. C.; GÜNTER, I. A. Ambientes restauradores: definição, histórico, abordagens e pesquisas. Estudos de Psicologia, v. 18, n. 3, p. 487-495, 2013.

GUIDO, P. C. et al. The state of the integrative medicine in Latin America: the long road to include complementary, natural, and traditional practices in formal health systems. European Journal of Integrative Medicine, v. 7, p. 5-12, 2015.

HARTIG, T. Issues in restorative environments research: matters of measurement. In: FERNÁNDEZRAMIREZ, B. et al. (ed.). CONGRESO PSICOLOGÍA AMBIENTAL, 11., Almeria, 2011. Proceedings [...] Almeria: Universidad de Almeria, 2011.

HEATHCOTE, E. A Healthy Architecture: The idea of the Hospital. In: JENCKS, C. The Architecture of Hope. Londres: Francis Lincoln, 2015.

HORRIGAN, B. et al. Integrative Medicine in Americ: how integrative Medicine is being practiced in clinical centers across the United States. Global Advances in Health and Medicine, v. 1, n. 3, p. 18-94, 2012.

HU, X.Y. et al. Defining Integrative Medicine in narrative and systematic reviews: a suggested checklist for reporting. European Journal of Integrative Medicine, v. 7, p. 76-84, 2015.

IYENDO, T. O.; UWAJEH, P. C.; IKENNA, E. S. The therapeutic impacts of environmental design interventions on wellness in clinical settings: a narrative review. Complementary Therapies in Clinical Practice, v. 24, p. 174-188, 2016.

JOYE, Y.; VAN DEN BERG, A. Restorative environments. In: STEG, L.; VAN DEN BERG, A.; GROOT, J. I. M. (ed.). Environmental Psychology: an introduction. New Jersey: Wiley-Blackwell, 2012.

KAPLAN, S. The restorative benefits of nature: toward an integrative framework. Journal of Environmental Psychology, v. 15, p. 169-182, 1995.

LANKSTON, L. et al. Visual art in hospitals: case studies and review of the evidence. Journal of the Royal Society of Medicine, v. 103, p. 490-499, 2010.

LOMBARDO, T. J. The reciprocity of perceiver and environment: the evolution of James J. Gibson’s ecological Psychology. Londres: Lawrence Erlbaum Associates, 1987.

MAIZES, V.; RAKEL, D.; NIEMIEC, C. Integrative medicine and patient-centered care. EXPLORE, v. 5, n. 5, p. 277, 2009.

MALARD, M. L. As aparências em Arquitetura. Belo Horizonte: Editora UFMG, 2006.

MINAYO, M. C. S. O desafio do conhecimento: pesquisa qualitativa em saúde. São Paulo: HucitecAbrasco, 1994.

OTANI, M. A. P.; BARROS, N. F. de. A Medicina Integrativa e a construção de um novo modelo na saúde. Ciência \& Saúde Coletiva, v. 16, n. 3, p. 1801-1811, 2011.

PALLASMAA, J. Body, mind and imagination: the mental essence of architecture. In: ROBINSON, S.; PALLASMAA, J. (org.). Mind in architecture: Neuroscience, Embodiment and the Future of Design. Cambridge: MIT Press, 2015. 
PIZZOLATO, P. P. B. O espaço arquitetônico como elemento terapêutico: a função da ambiência na recuperação e na qualidade de vida do paciente internado. São Paulo: USP, 2014.

SABBAG, S. H. F et al. A Naturologia no Brasil: avanços e desafios. Cadernos de Naturologia e Terapias Complementares, Palhoça: Editora Unisul, v. 2, p. 11-31, 2013.

SCHWEITZER, M.; GILPIN, L.; FRAMPTON, S. Healing spaces: elements of environmental design that make an impact on health. The Journal of Alternative and Complementary Medicine, v. 10, n. 1, 2004.

SHEPLEY, M. M.; PASHA, S. Design research and Behavioral Health Facilities. The Center for Health Design, 2013.

SHRAIKY, J. Prescribing Architecture: a critical evaluation of how design impacts health and wellness. Journal of Healthcare, Science and the Humanities, v. 1, n. 1, 2011.

STERNBERG, E. Healing spaces: the science of place and well-being. Cambridge: The MIT Press, 2009.

TESSER, C. D. (org.). Medicinas complementares: o que é necessário saber (homeopatia e medicina tradicional chinesa/ acupuntura). São Paulo: Editora UNESP, 2010.

TESSER, C. D. (org.). Práticas complementares, racionalidades médicas e promoção da saúde: contribuições pouco exploradas. Cadernos de Saúde Pública, Rio de Janeiro, v. 25, n. 8, p. 1732-1742, 2009.

THOMSON, H.; PETTICREW, M. Is housing improvement a potential health improvement strategy? Copenhagen: WHO Regional Office for Europe, 2005.

TISSOT, J. T. Definição de atributos arquitetônicos essenciais para a humanização em quartos de internação. Florianópolis: UFSC, 2016.

TOLEDO, L. C. Feitos para curar: arquitetura hospitalar e processo projetual no Brasil. Rio de Janeiro: ABDEH, 2006.

ULRICH, R. Effects of healthcare environmental design on medical outcomes. Design \& Healthcare World Congress \& Exhibition, Stockholm, p. 49-59, 2000.

ULRICH, R. Effects of interior design on wellness: theory and recent scientific research. Journal of Health Care Interior Design, v. 3, n. 1, p. 97-109, 1991.

ULRICH, R. et al. The role of the physical environment in the hospital of the 21st Century: a once-in-aLifetime Opportunity. The Center for Health Design, 2004.

ULRICH, R. View through a window may influence recovery from surgery. Science, v. 224, p. 420-421, 1984.

VALADARES, C. Ministério da Saúde inclui 10 novas práticas integrativas no SUS. Portal do Ministério da Saúde, Notícias, 2018. Available: http://portalms.saude.gov.br/noticias/agencia-saude/42737-ministerioda-saude-inclui-10-novas-praticas-integrativas-no-sus. Access: 18 set. 2018.

VAN DEN BERG, A. E. Health impacts of healing environments: a review of evidence for benefits of nature, daylight, fresh air, and quiet in healthcare settings. Groningen: Foundation 200 years University Hospital Groningen, 2005.

VILLELA, M. S. A ambiência nas Práticas Integrativas e Complementares: estímulos ao bem-estar do usuário. Florianópolis: Universidade Federal de Santa Catarina, 2017.

WORLD HEALTH ORGANIZATION. WHO Constitutio., 48 ${ }^{\text {th }}$. ed. Genebra: WHO Press, 2014.

WORLD HEALTH ORGANIZATION. WHO Traditional Medicine Strategy 2002-2005. Genebra: WHO Press, 2002.

WORLD HEALTH ORGANIZATION. WHO Traditional Medicine Strategy 2014-2023. Genebra: WHO Press, 2013.

\section{Acknowledgements}

The authors would like to thank everyone who supported and enabled the research, especially the interviewees and the institutions surveyed.

They would also like to thank the Coordenação de Aperfeiçoamento Pessoal em Nível Superior (CAPES) for the financial support. 


\section{Mariana Silva Villela}

Programa de Pós-Graduação em Arquitetura e Urbanismo | Universidade Federal de Santa Catarina | Rod. Amaro Antônio Vieira, $2489 / 602$ | Florianópolis - SC - Brasil | CEP 88034-102 | Tel.: (48) 99935-9439 | E-mail: arq.marianavillela@gmail.com

\section{Vera Helena Moro Bins Ely}

Programa de Pós-Graduação em Arquitetura e Urbanismo | Universidade Federal de Santa Catarina | Rua Prof. Marcos Cardoso Filho, 597

| Florianópolis - SC - Brasil | CEP 88037-040 | Tel.: (48) 99915-7288 | E-mail: vera.binsely@gmail.com

\section{Ambiente Construído}

Revista da Associação Nacional de Tecnologia do Ambiente Construído

Av. Osvaldo Aranha, 99 - 3o andar, Centro

Porto Alegre - RS - Brasil

CEP 90035-190

Telefone: +55 (51) 3308-4084

Fax: +55 (51) 3308-4054

www. seer. ufrgs. br/ ambienteconstruido

E-mail: ambienteconstruido@ufrgs.br

(c) (i) This is an open-access article distributed under the terms of the Creative Commons Attribution License. 